УДК 371.7

https://doi.org/10.36906/FKS-2021/05

Алексеева О.П.

Нижневартовский государственный университет,

г. Нижневартовск, Россия

\title{
ФИЗИЧЕСКОЕ ВОСПИТАНИЕ ОБУЧАЮЩИХСЯ МЛАДШИХ КЛАССОВ С ИСПОЛЬЗОВАНИЕМ РАЗНООБРАЗНЫХ СРЕДСТВ АЭРОБНОЙ ГИМНАСТИКИ
}

Аннотация. Аэробная гимнастика является эффективным средством физического воспитания в младшем школьном возрасте. У данного вида двигательной активности имеются огромные потенциальные возможности ее использования в школьном учебновоспитательном процессе. Применение разнообразных упражнений аэробной гимнастики в режиме учебного дня детей младшего школьного возраста способствуют умственному, нравственному, эстетическому и физическому развитию личности ребенка.

Ключевые слова: физическое воспитание, физкультурно-оздоровительная работа, спортивная деятельность, школьники, аэробная гимнастика.

Alekseeva O.P.

Nizhnevartovsk State University,

Nizhnevartovsk, Russia

\section{PHYSICAL EDUCATION OF STUDENTS IN LOWER CLASSES USING VARIOUS MEANS OF AEROBIC GYMNASTICS}

Annotation. Aerobic gymnastics is an effective means of physical education in primary school age. This type of physical activity has great potential for its use in the school educational process. The use of various exercises of aerobic gymnastics during the school day of primary school children contributes to the mental, moral, aesthetic and physical development of the child's personality.

Keywords: physical education, physical culture and health-improving work, sports activity, schoolchildren, aerobic gymnastics.

В настоящее время проблеме укрепления здоровья обучающихся в младших классах уделяется пристальное внимание. Особенную роль играет рациональное использование и сочетание двигательных режимов и физических упражнений, которые не только бы удовлетворяли современные требования к организации учебно-воспитательного процесса детей, но и соответствовали закономерностям развития физических качеств.

В младшем школьном возрасте происходят существенные изменения в личностном и психическом развитии ребенка: качественно перестраивается познавательная сфера, складывается трудная система отношений с ровесниками и взрослыми. Данный возраст связан с переходом ребенка к регулярному школьному обучению. Начало обучения в школе ведет к коренному видоизменению социальной ситуации развития младшего школьника.

Ведущей в младшем школьном возрасте становится учебная деятельность. Она определяет важнейшие изменения, происходящие в личностном развитии детей на данном возрастном периоде. Главная роль учебной деятельности не исключает того, что младший 
школьник инициативно включен и в другие виды деятельности - игру, физическую культуру, спорт, общение и т.д. [2, с. 33].

Переход к регулярному обучению формирует условия для развития познавательных потребностей детей, интереса к окружающей действительности, к овладению новыми знаниями и умениями. Данный возраст является периодом интенсивного развития и качественного формирования познавательных процессов. Ребенок учится управлять восприятием, вниманием и памятью.

Анализ и обобщение данных научно-методической литературы показал, что одним из эффективных средств укрепления и сохранения здоровья, повышения уровня физической подготовленности и мотивации к занятиям физической культурой и спортом является аэробная гимнастика, которая обладает огромной возможностью комплексного воздействия на физическое и психоэмоциональное состояние обучающихся в младших классах.

Аэробная гимнастика является действенным видом двигательной активности, оказывающим многостороннее воздействие на двигательные и психомоторные способности обучающихся в младших классах. В настоящее время, существенное снижение показателей здоровья обучающихся младших классов привлекает внимание многих специалистов в области физической культуры и спорта. Недостаточная двигательная активность обучающихся в младших классах ведет в дальнейшем к заболеваниям сердечно-сосудистой системы, формированию патологии костно-мышечной системы, а также к повышению случаев травматизма у детей.

Тенденция ухудшения физического состояния детей происходит в силу их ограничения естественных двигательных локомоций вследствие особенностей построения режима дня младшего школьника. Специалисты в области теории и методики физического воспитания говорят о потенциальной возможности применения упражнений аэробной гимнастики, как рационального средства физического воспитания в учебно-воспитательном процессе в младших классах [1, с. 53].

Формирование организма ребенка, уровень его функциональных возможностей и работоспособности в большой степени зависят от его двигательной активности. Небольшая по объёму двигательная активность и интеллект ребенка имеют прямую связь. Так, при плохой организации двигательного и учебного режима у ребенка понемногу пропадает потребность в двигательной активности, отмечается понижение умственной и физической работоспособности. В результате это сказывается на снижении запаса приобретенных двигательных навыков. Вследствие этого, они демонстрируют более низкий уровень развития физических качеств. Гиподинамия создает неблагоприятные условия и для умственного развития ребенка, понижает его физическую работоспособность.

Систематические занятия физической культурой, в частности, оздоровительной гимнастикой, способствуют комплексному развитию всех органов и систем, и существенным образом двигательного аппарата детей младшего школьного возраста. Совершенствуется координация движений и силовые способности, повышается возбудимость мышц, темп, мышечный тонус и т.д. Физические нагрузки, которые характерны для занятий аэробной гимнастикой оказывают многостороннее положительное влияние на организм обучающихся в младших классах.

В настоящее время, в структуре свободного времени большинства детей преобладают малоподвижные формы организации досуга и отдыха. Значительную часть своего свободного времени они проводят у экранов различных гаджетов. В результате этого снижается уровень их двигательной активности, увеличивается нагрузка на нервную систему, что в свою очередь приводит к существенному ухудшению физического состояния и в дальнейшем, к появлению 
различных заболеваний. Ведь именно заложенный в детском возрасте потенциал здоровья, интеллекта, физической работоспособности и творческой активности реализуется на протяжении всей последующей жизни человека.

Сегодня, здоровье ребенка определяет возможность и потенциал современного общества жить сегодня и полноценно развиваться в будущем. В связи с этим возрастает необходимость применения оздоровительных технологий в учебно-воспитательный процесс общеобразовательной школы. Актуальным остается вопрос разработки новейших эффективных физкультурно-оздоровительных методик и технологий обучающихся и поиска рациональных сочетаний средств и методов обучения. Это позволит увеличить интерес у занимающихся к регулярным занятиям физической культурой и спортом, активизировать двигательную активность на уроках и внеурочное время, способствовать комплексному развитию двигательных качеств, формированию здорового образа жизни

Обеспечить полноценность и биологическую потребность в движении в современном укладе жизни и в семье весьма сложно. Загруженность младшего школьника в течение учебного дня соединена с неподвижным сидением за партой и компьютером. Не рациональное распределение выполнения физических упражнений не всегда способствует положительным сдвигам в здоровье, что может способствовать в дальнейшем развитию болезней, снижению функциональных параметров, что может привести к инфекциям и простудам.

Комплексы упражнений аэробной гимнастики способствуют не только увеличению и оптимизации объёма двигательной активности, но и помогают формировать чувство темпа и ритма, красоту, грациозность и выразительность движений [3, с. 155]. Анализ научнометодической литературы свидетельствует о том, что в современной школе реализуемая программа по физическому воспитанию не в полной степени удовлетворяет потребность детей в двигательной активности и деятельности. Рациональная организация двигательного и учебно-воспитательного процесса младших школьников должна способствовать укреплению их здоровья, развитию основных физических качеств и удовлетворению их двигательных потребностей.

Занятия гимнастическими упражнениями под музыку имеют давнюю историю. В античные времена в Греции одной из разновидностей гимнастики была орхестрика. Гимнастика танцевального направления она использовалась для формирования правильной осанки, красивой походки, пластичности и грациозности движения. Значительное влияние на развитие и становление технико-эстетических видов гимнастики оказали Жорж Демени, Франсуа Дельсарт, Айседора Дункан. Физиолог Жорж Демени предложил систему физических упражнений, основанную на ведущем значении ритма и гармонии движений, ритмичном чередовании расслабления и напряжения мышц, а также, принципу поточности движений.

Айседора Дункан оказала значительное влияние на формирование ритмопластического направления, что и дало начало становления современной художественной гимнастики. Профессор Эмиль - Жак Далькроз объединил музыку, танец и ритмические движения в единую систему под названием - ритмическая гимнастика [4. с. 34].

В начале XX века в России происходило бурное развитие танцевально-ритмического направления. В Европе появилась джаз-гимнастика, а в Америке развивается направление под названием «аэробные танцы». Эра аэробики семидесятых годов XX века началось с системы доктора Кеннета Купера, который впервые применил термин «Аэробика». В это понятие он включил ходьбу, бег, плавание, лыжную подготовку, занятия конькобежным и велосипедным спортом, прыжки через скакалку и танцы. Система доктора Купера в один миг завоевала 
популярность во всем мире. Кроме аэробных физических занятий она основывалась на рациональном питании и психологическом комфорте [5, с. 43, 6, с.42].

На сегодняшний момент, аэробная гимнастика, является инновационным и современным видом оздоровительной физической культуры и обладает специфическими особенностями, большим разнообразием средств и возможностей многофункционального их использования с целью оздоровительного воздействия на опорно-двигательный аппарат, дыхательную, сердечно-сосудистую и нервную системы организма занимающихся.

Аэробная гимнастика является универсальным видом физической активности, оказывающим многостороннее воздействие на функциональные, двигательные, психомоторные способности человека. Кроме этого, совокупность факторов, которыми сопровождаются занятия аэробной гимнастикой (музыкальное сопровождение, занятия в коллективе и т. д.) оказывают благоприятное воздействие на личность обучающихся в младших классах.

Упражнения, используемые в комплексах аэробной гимнастике, не только способствует повышению двигательной активности, но и способствуют формированию двигательных способностей и коррекции осанки. Причем, соблюдаемая определенная последовательность упражнений, включаемых в комплексы аэробной гимнастики, веселая и современная музыка, исключают монотонность проводимых занятий.

Несмотря на огромную популярность аэробной гимнастики, ее высокую научную обоснованность, это система упражнений пока не полностью стала ведущим элементом школьной программы по физическому воспитанию и недостаточно полно используется как средство развития двигательных локомоций и способностей у детей младшего школьного возраста [7, с. 45].

На занятиях аэробной гимнастикой в младшем школьном возрасте упражнения подбираются, соблюдая строгую последовательность, постепенно усложняя двигательные поручения, подключая игровые моменты. В младшем школьном возрасте способность к усвоению новых фигур движений определяется уровнем развития основных физических качеств.

На занятиях по аэробной гимнастике формируется положительная эмоциональная атмосфера, закладывается и расширяется база знаний о правильном питании, а также об упражнениях для укрепления определенных мышечных групп и их выполнении в домашних условиях. Также, происходит приобщение к состязательным формам аэробной гимнастики.

Мы предполагаем провести исследование по разработке и экспериментальной проверке эффективности проведения занятий по физической культуре в школе с применением комплексов упражнений аэробной гимнастики. Для этого, в настоящее время, изучена специальная научно-методическая литература по применению многообразных средств аэробной гимнастики в младших классах. Обоснована актуальность и значимость темы исследования, определены задачи и методы исследования, обозначена гипотеза и выдвинуты основные положения, а также будет проведен педагогический эксперимент и сформулированы выводы по результатам проведенного исследования.

\section{Литература}

1. Анфинова С.И. Актуальность проблемы физического здоровья современных школьников // Здоровье, физическая культура и спорт в высшей школе: опыт проблем и перспективы. Сборник материалов Всероссийской заочной научно-практической конференции, посвященной 85-летию Института физической культуры, спорта и молодежной политики. 2018. С. 52-57. 
2. Борилкевич В.Е. Фитнесс - современное понятие в мировом оздоровительном движении // Термины и понятия в сфере физической культуры: Материалы международного конгресса. СПб.: СПбГУФК им. П.Ф. Лесгафта, 2006. С. 33-35.

3. Манжелей И.В., Чаюн Д.В. Психологическое сопровождение подготовки спортсменов в аэробной гимнастике // Вестник Томского государственного университета. 2018. №434. С. 155-161.

4. Поздеева Е.А., Пшеничникова Г.Н., Коричко Ю.В. Модельные характеристики содержания соревновательных упражнений квалифицированных гимнастов в спортивной аэробной гимнастике // Теория и практика физической культуры. 2018. №10. С. 33-35.

5. Пшеничникова Г.Н., Власова О.П., Коричко Ю.В. Обоснование рассредоточенного применения упражнений на гибкость в художественной гимнастике на этапе начальной подготовки // Физическая культура: воспитание, образование, тренировка. 2010. №5. С. 42-49.

6. Пшеничникова Г.Н., Коричко Ю.В., Печеневская Н.Г. Эволюция содержания ритмопластических движений в процессе становления художественной гимнастики // Физическая культура: воспитание, образование, тренировка. 2016. №5. С. 41-44.

7. Чаюн Д.В. Анализ содержания соревновательных программ в спортивной аэробике // Инновации в спорте, туризме и образовании - ICISTIS 2016: Материалы I Международной конференции. Челябинск: ЮУрГУ, 2016. С. 43-49.

(C) Алексеева О.П., 2021 